\title{
STUDY OF SPRINGS WATER QUALITY AS SOURCES OF POTABLE WATER AND FOR IRRIGATION IN REZINA DISTRICT
}

\author{
Maria Sandu*, Elena Mosanu ${ }^{a}$, Viorica Gladchi ${ }^{\mathrm{b}}$, A. Tarita ${ }^{\mathrm{a}}$, Gh. Duca ${ }^{\mathrm{c}}$, P. Spataru ${ }^{\mathrm{a}}$, \\ T. Lupascuc, E. Sergentu, Raisa Lozan ${ }^{\mathrm{a}}$, V. Jabin ${ }^{\mathrm{a}}$, S. Turcan ${ }^{\mathrm{b}}$ \\ ${ }^{a}$ Institute of Ecology and Geography, ASM, 1, Academiei str, Chisinau, MD - 2028. \\ ${ }^{b}$ State University of Moldova, Department of Chemistry. 60, Mateevici str. \\ ${ }^{c}$ Institute of Chemistry, ASM, 3, Academiei str. \\ *E-mail: ieg@asm.md,tel/fax (373 22) 211134
}

\begin{abstract}
A spring is a component of the hydrosphere, where water flows on to the surface of the earth from below the surface. Thus it is where the aquifer surface meets the ground surface. It may be the result of karsts topography where surface water has infiltrated the Earth's surface, becoming part of the area groundwater. As sources of water supply in the Republic of Moldova underground waters constitute 15,2\% (bore holes, springs and wells). The present work includes water quality investigations and aims to reveal local sources in river Nistru hydrographic basin (Rezina district) for drinking water provision in villages. Chemical composition of investigated spring's water shows that in Rezina district $19 \%$ of springs are polluted with nitrogen compounds. Water of only $9 \%$ of springs is in conformity with the standard for drinking water. Water from 102 springs meets the requirements of irrigation that doesn't present the risk of soil salinization $(\mathrm{K}>18)-1383 \mathrm{~L} / \mathrm{min}$.
\end{abstract}

Keywords: Spring, Groundwater, Water quality, Magnitude discharge, Water Types, Irrigation coefficients, Correlation coefficient.

\section{Introduction}

Groundwater from wells and springs is an important source of water supply and moves very slowly and follows the least resistive (most permeable) pathway from the point of recharge (where water enters the aquifer) to the point of discharge (where water leaves the aquifer).

In addition to wells, springs provide a source of water supply from aquifers and form the headwaters of many streams and wads. Springs occur where the water table intersects the surface topography and are common where geologic structures, such as faults, provide an outlet for groundwater discharge. Springs represent visible discharge from aquifers; invisible or concealed discharges include seepages, evaporation, transpiration to plants, and hidden springs. Under natural conditions, aquifers discharge water in an amount proportional to the total annual infiltration (recharge).

A spring is a place on the earth's surface where groundwater emerges naturally. The water source of most springs is rainfall that seeps into the ground uphill from the spring outlet. Groundwater obtained from springs is similar to water pumped from shallow wells. Like shallow wells, springs may be contaminated by surface water or other sources on or below the ground surface. The range of natural and man-induced pollutants includes nitrates, pesticides, sulfates, etc. [1]. Water hardness often exceeds the sanitary-hygienic standards by 2-5 times and more. The water quality in wells does not comply in the Republic of Moldova with the national standard for potable water: $87 \%$ of the shallow groundwater samples exceed the MAC for nitrate, but as sources of water supply underground waters constitute $15,2 \%$ (bore holes, springs and wells). Shallow aquifers are used for non-centralized water supply and the share of shallow groundwater in rural area reaches $95-100 \%$ from all water used [2].

Earlier it was investigate springs water quality in Briceni, Edinet, Rascani, Nisporeni Falesti and Glodeni districts $[3-5]$.

The object of this work is to evaluate springs water quality as sources of potable water and for irrigation in Rezina district and to classify spring's magnitude based on the summer value of discharge.

\section{Materials and Methods}

Sampling of water: several expeditions were organized to assess the springs water pollution and to collect samples in conditions to exclude water composition changes.

Sample preparation: water samples were analyzed without preventive storing using conventional methods of analysis. In springs water were determined the concentrations of macro- and nitrogen compounds, $\mathrm{pH}$ and other compounds. Ammonia ions were determined using the Nessler reagent [6-8]. Nitrite was estimated by the procedure

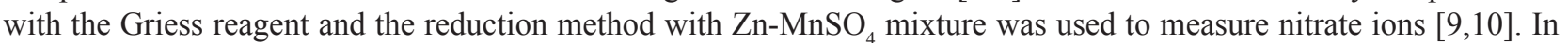
territory, were determined the location, temperature, flow, water odor and color. Reliability of analytical work has been checked using the internal standard.

Apparatus: DR/2500 spectrophotometer, $\mathrm{pH}$ meter, analytical balance, centrifuge.

Assessment of change in ions concentration was performed using mathematical statistics. 
Particularly important is the evaluation of the correlation between the basic components of water. Rank correlation coefficient $r$ Spearmen [6] is the most commonly used statistical characterization of the correlation between 2 sets of data because it is dimensionless and is not a relative size, it depends on the size of comparable values, but the report change.

\section{Results and discussions}

On 30.12.2005, in decision nr. 1406, the Government approved a „New Program of water supply and wastewater treatment for the settlements of the Republic of Moldova until 2015". Upon the implementation of the Program nearly half of the population will have access to centralized water services. As a priority of the Program, is mentioned the development of water distribution network, including and public wells/springs, recording and liquidation of pollution of water sources and prevent their pollution.

Springs have been used for thousands of years as an important source of water supply in the world and are places where groundwater discharges through natural openings in the ground. Springs flowing from water-table aquifers tend to have small, extremely variable flows and are influenced greatly by climatic conditions. There are some types of spring outlets: filtration springs with small flow rates in which the source water has filtered into permeable earth; fracture springs, discharge from faults, joints, or fissures in the earth and tubular springs which create underground channels, basically cave systems.

A spring flow is determined by the "spring's" recharge basin. Factors include the size of the area in which groundwater is captured, the amount of precipitation, the size of capture points, and the size of the spring outlet. Water may leak into the underground system from many sources including permeable earth, sinkholes, and losing streams.

Groundwater obtained from springs is similar to water pumped from shallow wells. Like shallow wells, springs may be contaminated by surface water or other sources on or below the ground surface. The groundwater is highly vulnerable to anthropoid impacts. Its quality is largely influenced by the geologic and geochemical conditions. While springs may seem to be good water supply, they need to be selected with care, developed properly, and tested periodically for contamination.

Today we face the challenge of protecting the springs from disappearing. Elevated nitrates content are a common and growing problem in springs. A steady rise in nitrate levels has been observed in springs over the past thirty years or so [11].

Contamination of groundwater from point and non-point sources is one of the major problems of water resources $[12,13]$. Altogether one hundred and nineteen groundwater samples were collected and investigated from Rezina district.

Water Quality. Groundwater quality can be affected by both natural and anthropogenic activities. In aquifers unaffected by human activity, the quality of groundwater results from geochemical reactions between the water and rock matrix as the water moves along flow paths from areas of recharge to areas of discharge. In general, the longer the groundwater remains in contact with soluble materials, the greater the concentrations of dissolved materials in the water [14]. The quality of groundwater also may be changed as the result of the mixing of waters from different aquifers. In aquifers influenced by human activity, the quality of water can be directly affected by the infiltration of anthropogenic compounds or indirectly - by the alteration of flow paths or geochemical conditions. The quality of water discharged by springs vary greatly because of factors such as the quality of the water that recharges the aquifer and the type of rocks with which the ground water is in contact. The rate of flow and the length of the flow path through the aquifer affect the amount of time the water is in contact with the rock, and thus, the amount of minerals that the water can dissolve.

Physical parameters. The measured $\mathrm{pH}$ values of the water in the present study range from 7,25 to 8,3 , thus classified as low alkaline. Spring-water temperatures range from 10 to $17^{\circ} \mathrm{C}$. It has not odor and color.

Chemical parameters. Spring water quality represents the general state of ground-water system. Most spring water in Rezina district is of good quality. The specific hardness generally is of 5 to 24,2 mmol/L: eleven springs with hardness less than $7 \mathrm{mmol} / \mathrm{L}$, sixty six - hardness of 7 to 10 and nineteen springs have very hard water (more than $10 \mathrm{mmol} / \mathrm{L}$ ) (fig. 1). The mineralization (total dissolved salts - TDS) ranges between of 356 to $1860 \mathrm{mg} / \mathrm{L}$ indicating that amounts of minerals are dissolved in the water. The minimum value of magnesium is about $10 \mathrm{mg} / \mathrm{L}$ (in Slobozia Horodiste) and the maximum about $168 \mathrm{mg} / \mathrm{l}$ (Meseni village). The concentration of $\mathrm{Na}^{+}+\mathrm{K}^{+}$ranges from $14 \mathrm{mg} / \mathrm{L}$ (in Cineseuti) to $221 \mathrm{mg} / \mathrm{L}$ (in Gordinesti). The concentration of chloride in the study area is of $14-148 \mathrm{mg} / \mathrm{L}$ and 345 $\mathrm{mg} / \mathrm{L}$ in Gordinesti. The highest concentration of sulfate was found in Meseni spring (446 mg/L), while the lowest concentration was $11 \mathrm{mg} / \mathrm{L}$ found in Echimauti. Water from only eleven (9\%) springs in Rezina district corresponds to the standard for drinking water (table 1). 
Water springs in Rezina district corresponding to the drinking water standard

\begin{tabular}{|l|l|l|l|l|l|l|}
\hline \multirow{2}{*}{ Village } & \multirow{2}{*}{ Ecological state } & \multicolumn{2}{|c|}{ Geographical coordinations } & Debit \\
\cline { 4 - 7 } & & & $\mathbf{N}$ & $\mathbf{E}$ & $\mathbf{h}(\mathbf{m})$ & $(\mathbf{L} / \mathbf{m i n})$ \\
\hline 1 & Pereni & Equipped, clean & $47^{\circ} 39.481$ & $028^{\circ} 46.384$ & 160 & 11,5 \\
\hline 2 & Pripiceni Razasi & Equipped, clean & $47^{\circ} 41.103$ & $028^{\circ} 45.643$ & 164 & 3,3 \\
\hline 3 & Pripiceni Razasi & Muddy & $47^{\circ} 41.192$ & $028^{\circ} 44.561$ & 157 & 14,6 \\
\hline 4 & Pripiceni Razasi & Non equipped & $47^{\circ} 41.558$ & $028^{\circ} 45.392$ & 190 & 17,6 \\
\hline 5 & Hartop & Equipped, clean & $47^{\circ} 43.291$ & $028^{\circ} 43.464$ & 233 & 6,4 \\
\hline 6 & Hartop & Equipped, clean & $47^{\circ} 43.291$ & $028^{\circ} 43.465$ & 200 & 5,4 \\
\hline 7 & Cineseuti & Need restoration & $47^{\circ} 41.323$ & $028^{\circ} 50.926$ & 188 & 1,4 \\
\hline 8 & Mateuti & Equipped, muddy & $47^{\circ} 48.264$ & $028^{\circ} 56.492$ & 166 & 37,5 \\
\hline 9 & Solonceni & Clean & $47^{\circ} 48.426$ & $028^{\circ} 59.407$ & 42 & 7,9 \\
\hline 10 & Lipceni & Equipped, need restoration & $028^{\circ} 52.690$ & 173 & 13,0 \\
\hline 11 & Lipceni & Equipped, need restoration & $47^{\circ} 48.422$ & $028^{\circ} 48.242$ & 170 & 8,2 \\
\hline Total & & & & $\approx \mathbf{1 3 0}$ \\
\hline
\end{tabular}

The nitrate concentrations in the study area range from $2 \mathrm{mg} / \mathrm{L}$ (in Trifesti village) to $314 \mathrm{mg} / \mathrm{L}$ (in Otac). Sixty nine springs (58\%) had nitrate concentrations exceeding the threshold value of $20 \mathrm{mg} / \mathrm{L}$, and 23 springs (19\%) from Buseuca, Otac, Cuizauca, Ignatei, Meseni, Cineseuti, Gordinesti, Tareuca, Mateuti, Mincenii de Sus, Echimauti villages had nitrate concentrations higher than $50 \mathrm{mg} / \mathrm{L}$, the maximum acceptable concentration (MAC) of nitrates for drinking water (exceeding MAC of one to five times) (fig. 1). There is a wide spatial variation in the nitrate concentration in spring water. Untreated domestic wastewater is most probably the major source of nitrate in the spring water. Moreover, in the area under consideration there are no major industries or intensive agricultural activities. The results of this study are useful to highlight one of the most important environmental problems, namely the degradation of water quality, and may serve to alert and encourage local and national authorities to take substantial steps and actions to protect and manage water quality.

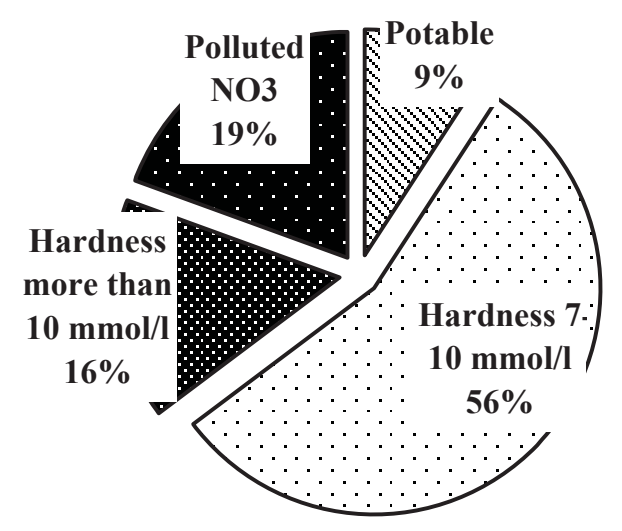

Fig. 1. Quota number of water springs: 1 - potable (9\%); 2 - hardness $7-10 \mathrm{mmol} / \mathrm{L}(56 \%) ; 3$ - hardness $>10$ $\mathrm{mmol} / \mathrm{L}(16 \%)$ and 4 - polluted with $\mathrm{NO}_{3}^{-}(19 \%)$.

Correlation coefficients. The correlation coefficient between any two variables is an important measure because it helps in identifying the strength and degree of relationship between them. Though much work has been done in developing different correlation measures, most of these are suitable only for crisp numbers.

Calcium, the most abundant dissolved cationic constituent of groundwater and responsible for water temporal hardness, ranges from $72 \mathrm{mg} / \mathrm{L}$ (in Pereni, Slobozia Horodiste villages) to $259 \mathrm{mg} / \mathrm{L}$ (in Otac village). The correlation coefficient of $\mathrm{Ca}^{2+}$ versus $\mathrm{HCO}_{3}^{-}$and $\mathrm{Cl}^{-}$, is 0,33 , and 0,11 , respectively. The content of $\mathrm{Ca}^{2+}$ has also high positive correlation coefficient with $\mathrm{NO}_{3}^{-}(0,21)$; it can be attributed to association of its compound in soil and utilized fertilizers or/and wastes non regularly deposits.

It is to mention that the content of nitrate ions correlated with hardness $[15,16]$. The values of correlation coefficient constitutes $\mathrm{R}^{2}=0,6488$ (fig. 2) that confirms the observed trend and indicates a clear influence of nitrogenous compounds (especially ammonia) on calcareous elements of the earth $[17,18]$. The coefficient for springs water with the content of $\mathrm{NO}_{3}^{-}$less than MAC is very small $(0,06)$. Was established an insignificant correlation of the $\mathrm{NO}_{3}^{-}$content with waters mineralization $\left(\mathrm{R}^{2}=0,1704\right)$ and practically absence with chloride and sulfate concentrations. 


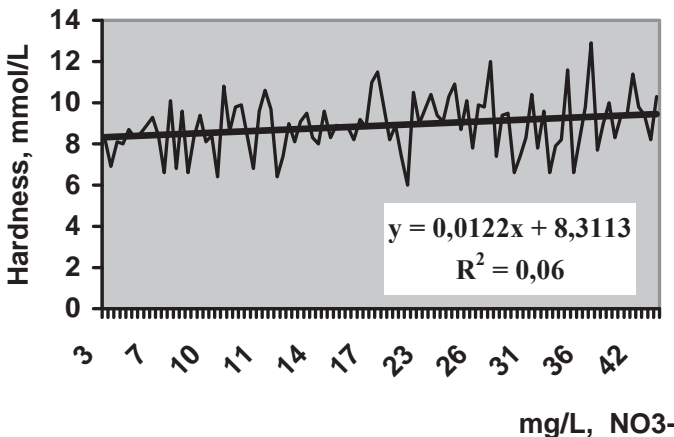

a)

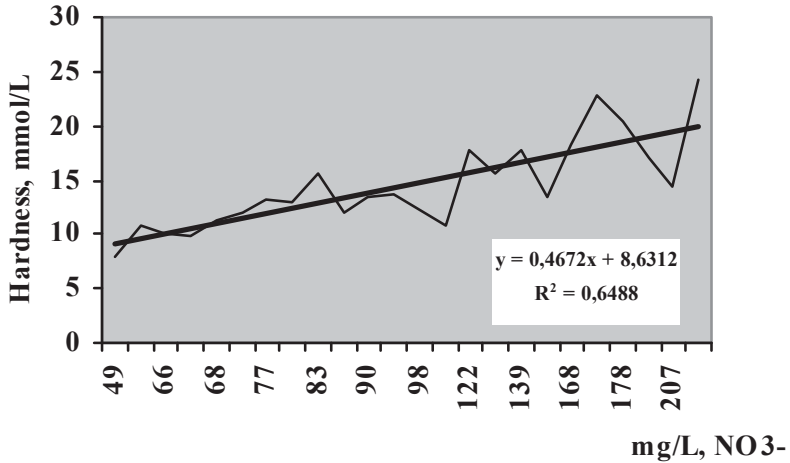

b)

Fig. 2. Correlation between water hardness and nitrates content. Regression equation and the credibility correlation coefficient $\left(R^{2}\right)$ : a) less than MAC; b) more than MAC nitrates content.

Water Types. In some cases, the ground water may exit from multiple vents. One vent may exhibit different water chemistry than another vent. These differences are sometime referred to as water types. The water type can be determined from the chemical content of a sample. Were established the following types of water springs in Rezina district on the basis of anions: $33 \%$ of $\mathrm{HCO}_{3}, 29 \%-\mathrm{HCO}_{3}-\mathrm{SO}_{4} / \mathrm{Cl}, 23 \%-\mathrm{HCO}_{3}-\mathrm{SO}_{4}, 5 \%-\mathrm{HCO}_{3} / \mathrm{Cl}_{-} \mathrm{SO}_{4}$ and about $10 \%$ of springs water is of nitrate type $\left(\mathrm{HCO}_{3}-\mathrm{SO}_{4}-\mathrm{Cl}-\mathrm{NO}_{3} ; \mathrm{HCO}_{3}-\mathrm{NO}_{3}-\mathrm{Cl}-\mathrm{SO}_{4} ; \mathrm{HCO}_{3}-\mathrm{NO}_{3}-\mathrm{Cl}\right)(\mathrm{fig}$. 3). Cations content in studied waters conditioned the presence of $\mathrm{Ca}-\mathrm{Mg} / \mathrm{Na}(88 \%), \mathrm{Mg}-\mathrm{Ca} / \mathrm{Na}(9 \%)$ and $\mathrm{Na}-\mathrm{Ca} / \mathrm{Mg}(3 \%)$ types of water.

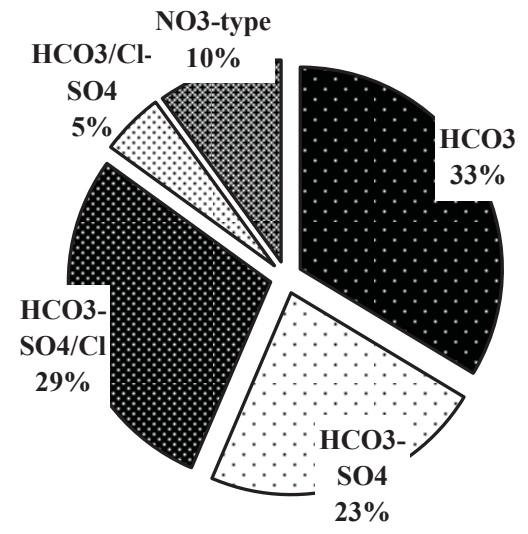

Fig. 3. Quota number of springs grouping on water type: $\mathrm{HCO}_{3}(33 \%) ; \mathrm{HCO}_{3}-\mathrm{SO}_{4} / \mathrm{Cl}(29 \%) ; \mathrm{HCO}_{3}-\mathrm{SO}_{4}$ $(23 \%) ; \mathrm{HCO}_{3}-\mathrm{Cl}(5 \%)$; and $10 \%$ nitrate type of springs water.

Classification of springs

Springs are classified by magnitude (from 1 to 8) on the basis of their volume of flow, or discharge of water [19].

First, second, third and fours magnitude springs discharge the greatest amount of water but are absent in the studied territory. There are eight 5th magnitude springs, seventy seven 6th magnitude springs, thirty-one 7th magnitude springs, plus another three springs classified as 8th magnitude. The following is a summary of spring classification by volume in Rezina district (table 2).

Table 2

The summary of spring classification by volume

\begin{tabular}{|l|l|l|}
\hline Magnitude & Flow L/min & Number of springs in Rezina district \\
\hline 1 st Magnitude & $>168000$ & 0 \\
\hline 2 nd Magnitude & 16800 to 168000 & 0 \\
\hline 3 rd Magnitude & 1680 to 16800 & 0 \\
\hline 4 th Magnitude & 378 to 1680 & 0 \\
\hline 5 th Magnitude & 37,8 to 378 & 8 \\
\hline 6 th Magnitude & 3,78 to 37,8 & 77 \\
\hline 7 th Magnitude & 0,48 to 3,78 & 31 \\
\hline 8 th Magnitude & $<0,48$ & 3 \\
\hline
\end{tabular}


Irrigation Water Criteria. Irrigation is an artificial application of water to the soil and is used to assist in the growing of agricultural crops, maintenance of landscapes, and revegetation of disturbed soils in dry areas and during periods of inadequate rainfall. Sources of irrigation water can be groundwater extracted from springs or by using wells, surface water withdrawn from rivers, lakes or reservoirs or non-conventional sources etc. Numerous parameters are used to define irrigation water quality. One criteria was used in this study for evaluating irrigation water quality - the Stebler irrigation coefficients [20]. All ionic concentrations $\left(\mathrm{Na}^{+}, \mathrm{Cl}^{-}, \mathrm{SO}_{4}^{2-}\right)$ are expressed in milliequivalent per liter.

The calculated irrigation coefficients for the water of 17 springs in Rezina district (s. Echimauti, Lipceni, Solonceni, Pereni, Otac, Pripiceni Razasi, Hartop, Peciste, Ignatei, Meseni - by one, Sarcova, Tareuca, Gordinesti - by two, Buseuca - by three) don't correspond to irrigation conditions $(K<18)$. As for the rest of the springs $(102)$ it doesn't present any danger of soil salinization $(\mathrm{K}>18)$ and water may be used with the purpose of irrigation.

\section{Conclusions}

The study shows the following results:

- The quality of water discharged by springs vary greatly because of factors such as the quality of the water that recharges the aquifer and the type of rocks with which the ground water is in contact. The rate of flow and the length of the flow path through the aquifer affect the amount of time the water is in contact with the rock, and thus, the amount of minerals that the water can dissolve.

- The measured $\mathrm{pH}$ values of the water in the present study range from 7,25 to 8,3, thus classified as low alkaline. Spring-water temperatures range from 10 to $17^{\circ} \mathrm{C}$. It has not odor and color.

- The groundwater in the study area falls under fresh (TDS $<1,000 \mathrm{mg} / \mathrm{l}$ ) to brackish (TDS $>1,000 \mathrm{mg} / \mathrm{l})$ type of water.

- Water from eleven (9\%) springs corresponds to the standard for drinking water.

- Most of the waters are unfit as drinking ones because of the $\mathrm{NO}_{3}^{-}(19 \%)$, hardness and TDS contents are as well high (72\%).

- Quota number of springs grouping on water type constitutes $33 \%$ for $\mathrm{HCO}_{3} ; 29 \%-\mathrm{HCO}_{3}-\mathrm{SO}_{4} / \mathrm{Cl} ; 23 \%$ $\mathrm{HCO}_{3}-\mathrm{SO}_{4} ; 5 \%-\mathrm{HCO}_{3}-\mathrm{Cl}$ and $10 \%$ nitrate type of springs water.

- As calculated, irrigation coefficients water for 17 springs in Rezina district (14\%) don't correspond to irrigation conditions $(\mathrm{K}<18)$. The rest of the springs $(102)$ don't present danger of soil salinization $(\mathrm{K}>18)$ and water may be utilized for irrigation.

\section{Recommendations}

Contamination sources of springs include livestock, wildlife, crop fields, forestry activities, septic systems, and fuel tanks located upslope from the spring outlet. To protect springs it is necessary to take the following measures.

1. As the quality of groundwater is a general problem, the government authorities are strongly advised to protect water supply over the long term.

2. The groundwater quality management should be attempted in the study area.

3. Prohibit flooding near the spring.

4. Construct a U-shaped surface drainage diversion ditch to divert any surface runoff away from the spring, but not to dig deep enough to uncover flowing groundwater.

5. Fence an area in all directions around the spring box to prevent contamination by animals and people who are unaware of the spring's location.

6. Avoid heavy vehicle traffic over the uphill water bearing layer to prevent compaction that may reduce water flow.

The investigation was realized in the frameworks of the State Program "Scientific and of management researches dealing water quality".

\section{References}

[1]. ТИТОВЕЦ М. Подземные воды Республики Молдова // Schimbarea chimiei. Cercetări, studii, soluții. Chişinău, 2000, - p. 81-83.

[2]. GÂlCĂ G., CUNICIAN L., SANDU M., OBUH P., TODERAŞ I.. State of Aquatic Resources. Republic of Moldova. State of the Environment Report in. 2005. Chsinau, 2006. p. 37-38.

[3]. TĂRÎȚĂ A., SANDU M., LOZAN R., SERGENTU E., SPĂTARU P., MOŞANU E., GOREACIOC T., JABIN V. Calitatea apei izvoarelor şi cişmelelor din raionul Nisporeni. //Buletinul AŞM. "Ştiințele vieții”, 2008, nr.1. - p. 164-169.

[4]. MOŞANU E., TĂRÎȚĂ A., SERGENTU E., SANDU M., SPĂTARU P., GOREACIOC T., JABIN V. Calitatea apei izvoarelor şi cişmelelor din raioanele Glodeni şi Făleşti (bazinul hidrografic al râului Prut). În: "Mediul Ambiant”, Chişinău: 2009, nr. 5(47), p. 1-4.

[5]. SANDU M., SERGENTU E., TĂRÎȚĂ A., SPĂTARU P., MOŞANU E., LOZAN R. Calitatea apei izvoarelor şi 
cişmelelor din bazinul hidrografic al răului Prut (r-le Briceni, Edineț, Rîşcani). // "Mediul Ambiant”, Chişinău: 2009, nr. 4(46), p. 36-40.

[6]. Standard methods for the examination of water and wastewater, 16 ed., APNA, AWWA, WPCE. 1985. p. 496 503.

[7]. ГОСТ 2874-82. Вода питьевая. - М.: Издательство стандартов. 1984. - 239 с.

[8]. Унифицированные методы исследования качества вод. Методы анализа вод, М.: Наука, 1983. 108 с.

[9]. ЛОЗАН Р., РОПОТ В., САНДУ М. Определение нитратов и нитритов в природных водах. Химия и технология воды.1989, т.11, N 2, с. 120-122.

[10]. ЛОЗАН Р., САНДУ М., В. РОПОТ. Способ определения нитратов. Авторское свидетельство Nr. 1638619 от 01.12.1990.

[11]. MUTEWEKIL M. Obeidat, FAYEZ Y. Ahmad, NEZAR A. Hamouri, ADNAN M. Massadeh and FAISAL S. Athamneh. Assessment of nitrate contamination of karst springs, Bani Kanana, northern Jordan. Revista Mexicana de Ciencias Geológicas, v. 25, núm. 3, 2008, p. 426-437.

[12]. САМАРИНА В.С., КОЗЛОВА Э.В., САРГСЯНЦ Н.А. Нитратное загрязнение верхнего водоносного горизонта Северной Молдавии. - В кн.: Гидрогеология и гидрогеохимия. Л., 1979, с. 30-36.

[13]. АХМЕТЬЕВА Н.П., ЛОЛА М.В., ГОРЕЦКАЯ А.Г. Загрязнение грунтовых вод удобрениями. М.: Наука, $1991,102 \mathrm{c}$.

[14]. КОЗИН А.Н. Основные факторы формирования подземных вод и оценка их роли. Формирование химического состава природных вод и процессы, протекающие в них// Гидрохимические материалы. 1985. T. 93. C. 37-53.

[15]. SANDU M. Corelarea dintre conținutul nitraţilor şi cel al macrocomponentelor din apele naturale//Bul. A.Ş.M. Seria şt. biol. şi chimice. 2004, Nr. 3, p. 116-119.

[16]. SANDU M., BOIAN I. Apa izvoarelor din Republica Moldova. //Mediul Ambiant, nr. 19. 2005, - p.10-14.

[17]. SANDU M., LUPAŞCU T., SPATARU P. The solubility of calcium carbonate in solutions of inorganic nitrogen compounds. The Second International Conference on Ecological Chemistry. October 11-12, 2002. Advanced and prospects of Ecological Chemistry. Chisinau, Republic of Moldova, Ştiința, 2002, p. 66.

[18]. SANDU M., LUPAŞCU T., SPĂTARU P. Solubilizarea carbonaților cu compuşi ai amoniului - factor perturbator al echilibrului ionilor de calciu în apele naturale// Mediul Ambiant. - nr. 5 (5). 2002. - p. 8-11.

[19]. ROSENAU J.C., FAULKNER G.L., HENDRY C.W. \& HULL R.W. (1977) Springs in Florida. Geol. Bull. No. 31 (revised). U.S. Geol. Sur. in cooperation with Florida Department of Natural Resources, Bureau of Geology, Tallahassee, Fl., 461 p.

[20]. НИКАНОРОВ А.М., ПОСОХОВ Е.В. Гидрохимия. - Л.: Гидрометеоиздат, 1985. - с. 252. 